\title{
IMPACT OF VERMICOMPOST EXTRACT APPLICATION INTO SOIL AND ON PLANT LEAVES ON MAIZE PHYTOMASS FORMATION
}

\author{
Peter Kováčik', Marek Renčo², Vladimír Šimanský3, Eva Hanáčková', Barbara Wiśniowska-Kielian ${ }^{4}$ \\ 1 Department of Agrochemistry and Plant Nutrition, Slovak University of Agriculture in Nitra, Tr. A. Hlinku 2, \\ 94901 Nitra, Slovakia, e-mail: Peter.Kovacik@uniag.sk \\ 2 Department of Plant Nematology, Slovak Academy of Sciences, Hlinkova 3, 04001 Košice, Slovakia, e-mail: \\ renco@saske.sk \\ ${ }^{3}$ Department of Soil Science and Geology, Slovak University of Agriculture in Nitra, Tr. A. Hlinku 2, 94901 Nitra, \\ Slovakia, e-mail: vladimir.simansky@uniag.sk \\ ${ }^{4}$ Department of Agricultural and Environmental Chemistry, University of Agriculture, A. Mickiewicza Ave. 21, \\ 31-120 Kraków, Poland, e-mail: rrkielia@cyf-kr.edu.pl
}

Received: 2015.06.06

Accepted: 2015.08.31

Published: 2015.10.01

\begin{abstract}
Nowadays in scientific literature many opposing data are presented of the impacts of vermicompost extract on the quantity and quality of crop production. Therefore, the principal objective of two independent experiments was to study the effects of vermiextracts, which were applied before maize sowing into soil and during the growing season on the maize leaves, on its phytomass formation. The first, field experiment consisted of 9 variants. Variant 1 was the control one without the extract application. We studied the effect of the rising doses $\left(90,130,170,210 \mathrm{dm}^{3} \cdot \mathrm{ha}^{-1}\right)$ of vermi-extract applied into soil before the maize sowing in the variants $\mathrm{E}_{1}, \mathrm{E}_{2}, \mathrm{E}_{3}, \mathrm{E}_{4}$. In the variants $\mathrm{E}_{1}+\mathrm{E}, \mathrm{E}_{2}+\mathrm{E}, \mathrm{E}_{3}+\mathrm{E}, \mathrm{E}_{4}+\mathrm{E}$ along with the rising doses of vermi-extract was also applied the uniform dose of vermi-extract $\left(40 \mathrm{dm}^{3} \cdot \mathrm{ha}^{-1}\right)$ at the growth stage $\mathrm{BBCH} 15$. The second, pot experiment was pursued in the vegetation cage and comprised 3 variants: variant 1 was the control, in the variants 2 and 3 the foliar application of vermi-extract was used. The vermi-extract was applied once (growth stage $\mathrm{BBCH} 12$ ) in the variant 2 and in the variant 3 it was used twice (at growth stages $\mathrm{BBCH} 12$ and $\mathrm{BBCH} 16$ ). The achieved results show that the vermi-extract applied in the presowing period increased the yield of maize grains if the application doses were $130-170 \mathrm{dm}^{3} \cdot \mathrm{ha}^{-1}$. The positive or negative impact of the foliar application by vermi-extract on the yield of maize grains depended on the period of application and the grown cultivar. In order to increase the starch content in grains it was more suitable to carry out the presowing vermi-extract application than during the growing season. The presowing application and the foliar application of vermi-extract tended to decrease the nitrogen content in grain. The foliar application of vermi-extract had the positive impact on the plant height and stalk thickness of the maize plants only in short term. The information obtained from the first half of maize growing season related to the plant height and stalk thickness was not the appropriate indicator for the assessment of maize grain yields.
\end{abstract}

Keywords: vermicompost, vermi-extract, foliar application, maize.

\section{INTRODUCTION}

Compost production has decreased continually in Slovakia since 1990 on the other hand the slight increase of the waste material production suitable for composting has been recorded.
The reasons are the considerable financial costs needed for the produced composts transportation, therefore the agricultural companies buy them in the limited volumes. One solution providing the continual composts production and also their sale consists in their final preparation, i.e. the produc- 
tion of liquid or dried composts. The effects of "the liquid composts", i.e. water extracts from composts and vermi-extracts on plants have been studied by the world scientists for many years [Ložek, Fecenko 1998, Ghorbani et al. 2008].

During the given period, both positive and negative results have been achieved. The main reason of the negative results is considered to be the fact that composts and also vermi-composts are produced from different kinds of waste, which causes that the undesirable matters are getting into extracts leading to the inhibitive even toxic impacts on crops. Therefore, it is necessary to utilize only clean components for the production of all types of composts which are used for the production of extracts [Kostecka 2009, Kováčik 2014].

If the appropriate components are used for the production of vermicomposts and subconsequently vermi-extracts, these matters can have a positive impact on the phytomass formation of the cultivated crop [Tejada et al. 2008, Singh et al. 2010]. The use of vermi-extracts in the diluted form eliminates their potential negative impacts on crops [Gutiérrez-Miceli et al. 2008].

In spite of the recorded positive and negative effects, the evidential and unevidential effects of vermi-extracts on the seed germination and yield of crops was observed [Frederickson 2002, Zaller 2006]. It is important to emphasize that the majority of the experiment results shows a positive impact of the foliar application of vermi-compost extracts on the chlorophyll and phytomass formation of the cultivated crops [Arancon et al. 2004, Edwards 1998, Pant et al. 2009]. It is recommended to add either a small quantity of $\mathrm{N}$ or NPK fertilizers, or the fertilizers containing $\mathrm{Cu}$, $\mathrm{Zn}, \mathrm{B}$, etc. into the vermi-extracts [Ingham 2005, Gutiérrez-Miceli et al. 2008, García-Gómez et al. 2008]. Depending on the dose and growth stage of plants the foliar application of vermi-extracts increases yields in a rather extensive scale, $i$. e. from $5 \%$ to $27 \%$ and sometimes by $35 \%$ [Kováćik 2014]. The recorded positive effect of the vermicompost extracts (often enriched by NPK fertilizers) on a plant is not the result of percolated nutrients content but predominantly it is the result of impact of the percolated humic acids and fulvo acids, the growth regulators - auxins, giberelins and cytokinins [Grappelli et al. 1987, Tomati et al. 1988, Tomati, Galli 1995, Arancon et al. 2005, Pant et al. 2012].

The world research of the vermi-compost extracts utilization deals also with the study of their impact on the state of health. There are many recorded cases of their positive effect on the inhibition of the plant diseases [Weltzien 1991, Scheuerell, Mahaffee 2002, Utkhede, Koch 2004, Lanthier 2007, Singh et al. 2008].

In the USA several firms sell the extracts from vermi-composts as a pesticide. However, the impact of extracts on the inhibition of diseases lags behind considerably in comparison with the existing chemical pesticides [Wickland et al. 2001]. The annual growth of the extracts sold in this way represented $25 \%$ in the USA in $2002-2008$. In spite of this fact, several scientific publications have been presented in the USA, which had not proved the fungicidal effect of vermi-extracts [Lanthier 2007, Chalker-Scott 2005].

The existence of several opposing findings related to the vermi-extracts impacts on the soil microflora, on the crop health and on the quantity and quality of the crop production requires researchers intensify research in order to study the reasons of different impacts of vermi-extracts [Scheuerell 2004].

In order to optimize the plant nutrition, predominantly related to nitrogen nutrition, the growers are recommended to monitor the nutrients content in plants, the amount of formed phytomass and chloropyll content during the growing season. Kmet'ová and Kováčik [2014] registered almost the same strong relationship between the height of maize plants and grain yield, or between the thickness of plant stalks and grain yield as well as between the chlorophyll content and grain yield. Based on this fact they claim that the information about the plant height and stalk thickness detected in the growth stages BBCH 14 till BBCH 18 indicates properly the quantity of maize yield. The data about the relationship between the maize stalk thickness and the quantity of grain yield, or between the maize height and grain yield detected in the later growth stages are scarce and there is no studies in this subject in the Slovak.

The main objective of experiments was to acquire data about the impacts of vermi-extract applied into soil and to broaden the existing knowledge about the impacts of vermi-extract applied on the plant leaves on the maize phytomass formation. The secondary objective was to complete the data about the possibility of usage the information about the plant height and stalk thickness for the purpose of maize grain yield prognosis. 


\section{MATERIAL AND METHODS}

The impact of the vermi-compost extract applied into soil and on plant leaves on the maize phytomass formation was studied in two independent experiments. The first field experiment was a semi-operational one carried out in the cadastre of village Opatovská Nová Ves (4806 $\left.{ }^{\prime} \mathrm{N}, 19^{\circ} 16^{\prime} \mathrm{E}\right)$, district of Vel'ký Krtíš, on Loamy Luvisol. The second experiment was pot one pursued on the Haplic Fluvisol in the vegetation cage located in the premises of the Slovak University of Agriculture in Nitra $\left(48^{\circ} 18^{\prime} \mathrm{N}, 18^{\circ} 05^{\prime} \mathrm{E}\right)$. The agrochemical parameters of soils on which the experiments were carried out are given in the Table 1.

The following analytical methods were used to determine soil parameters: $\mathrm{NH}_{4}^{+}-\mathrm{N}-$ colorimetrically by Nessler agent and $\mathrm{NO}_{3}^{-}-\mathrm{N}-$ colorimetrically by the phenol-2,4-disulfonic acid after extraction from soil by the $1 \% \mathrm{~K}_{2} \mathrm{SO}_{4}$ water solution; inorganic nitrogen content was calculated as $\mathrm{N}_{\mathrm{an}}=\mathrm{NH}_{4}^{+}-\mathrm{N}+\mathrm{NO}_{3}^{-}-\mathrm{N}$; $\mathrm{P}$ was determined colorimetrically, $\mathrm{K}$ and $\mathrm{Ca}$ - by flame photometry and $\mathrm{Mg}$ - by atomic absorption spectrophotometry in extract acc. to Mehlich III method [Mehlich 1984]; $\mathrm{C}_{\mathrm{ox}}$ - oxidometrically [Tiurin 1966]; $\mathrm{N}_{\mathrm{t}}-$ by Kjeldahl distilation method [Bremner 1960] in the modifications for soils and organic substrates [Kováčik 1997]. The content of organic matters was determined by the gravimetric analysis, temperature $550-600{ }^{\circ} \mathrm{C}$ [Kováčik 1997], $\mathrm{pH} / \mathrm{KCl}$ - potentiometrically in the extract $1.0 \mathrm{~mol} \cdot \mathrm{dm}^{-3}$ $\mathrm{KCl}$ solution [Fiala et al. 1999].

The vermi-compost extract was obtained after two-day taking interfusion of the vermi-compost mixture and potable water, with the ratio between compost and water as $1: 10(\mathrm{~m} / \mathrm{v})$. Subsequently, the mixture was settling for 24 hours. After the sedimentation of the solid particles the upper, liquid part was decanted. The parametres of the used vermi-extract are given in Table 2 . The vermicompost was produced from the compost consisting of cow dung (cca 50\%), sheep dung (cca $10 \%$ ), green grass (cca 10\%) and wood chips (30\%) fermented for 3-4 months. After that period, $1 / 5$ of the older vermi-compost containig earthworms and cocoons of earthworms was added to the whole volume of compost. One $\mathrm{dm}^{3}$ of old vermicompost contained 70 earthworms with an average weight of 0.42 grams per creature. The newly-formed compost was transported to the halls with appropriate ventilation and it was piled up the height of $30 \mathrm{~cm}$. There the compost fermented for 120 days with concurrence of earthworms and the earthworms were engrossed by the crushed fruit $(300 \mathrm{~kg})$ and vegetables $(100 \mathrm{~kg})$ of the total amount $400 \mathrm{~kg}$ of fodder per month and $1 \mathrm{Mg}$.

The field experiment consisted of 9 variants described in Table 3 with three repetitions and it was based on the method of long parcels of land, and each field had the width of 18 metres and length of 110 metres.

The test crop was maize, cultivar Stira, FAO 420 sown 65,000 grains per hectare. The variant 1 was control, without the extract application. The increased doses of vermi-extract were applied into soil in the variants 2 to 9 during the spring soil preparation. The doses of vermi-extract were identical in the pairs of variants 2 and 3, 4 and 5, 6 and 7,8 and $9\left(90,130,170,210 \mathrm{dm}^{3} \cdot \mathrm{ha}^{-1}\right.$, respectively), five days before the maize sowing. The uniform dose $\left(40 \mathrm{dm}^{3} \cdot \mathrm{ha}^{-1}\right)$ of vermi-extract in a form of the foliar application was used in the unpaired variants $(3,5,7,9)$ during the growth stage BBCH 15 using the sprinkler of 18 metres span.

The maize harvest was carried out in the growth stage $\mathrm{BBCH} 97$ by the six-row combine. The maize grain from each variant was transported by a truck to the drier where it was weighed

Table 1. Soil agrochemical parameters before the foundation of experiments in a soil layer $0.0-0.3 \mathrm{~m}$

\begin{tabular}{|c|c|c|c|c|c|c|c|c|c|c|}
\hline \multirow{2}{*}{ Experiment } & \multirow{2}{*}{ Soil } & \multirow{2}{*}{$\mathrm{pH}_{\mathrm{KCl}}$} & $\mathrm{N}_{\mathrm{an}}$ & $\mathrm{P}$ & K & $\mathrm{Ca}$ & $\mathrm{Mg}$ & $N_{t}$ & $\mathrm{C}_{\mathrm{ox}}$ & Org. M. \\
\hline & & & \multicolumn{4}{|c|}{$\mathrm{mg} \cdot \mathrm{kg}^{-1}$ d.m. } & \multicolumn{4}{|c|}{$\mathrm{g} \cdot \mathrm{kg}^{-1} \mathrm{~d} \cdot \mathrm{m}$} \\
\hline Field & Loamy Luvisol & 6.47 & 13.35 & 74 & 222 & 1,860 & 341 & 1,604 & 20.80 & 50.2 \\
\hline Pot & Haplic Fluvisol & 6.52 & 17.6 & 26 & 300 & 4,670 & 1,096 & 3,234 & 22.95 & 95.9 \\
\hline
\end{tabular}

Table 2. Parameters of vermi-extract

\begin{tabular}{|c|c|c|c|c|c|c|c|}
\hline $\mathrm{N}_{\mathrm{t}}$ & $\mathrm{P}_{\mathrm{t}}$ & $\mathrm{K}_{\mathrm{t}}$ & $\mathrm{Ca}_{\mathrm{t}}$ & $\mathrm{Mg}_{\mathrm{t}}$ & $\mathrm{HA}_{\mathrm{t}}$ & $\mathrm{FA}_{\mathrm{t}}$ & $\mathrm{pH}$ \\
\hline \multicolumn{7}{|c|}{$\mathrm{mg} \cdot \mathrm{dm}^{-3}$} \\
\hline 1,100 & 980 & 6,540 & 508 & 421 & 8,200 & 194 & 7.02 \\
\hline
\end{tabular}

Explanation: $\mathrm{t}$ - total, $\mathrm{HA}_{\mathrm{t}}$ - total humic acids, $\mathrm{FA}_{\mathrm{t}}$ - total free amino acids. 
Table 3. Variants of field experiment - the way of vermi-extracts application

\begin{tabular}{|l|c|c|c|}
\hline \multirow{2}{*}{ Variant } & \multicolumn{3}{|c|}{ Vermi-extract dose $\left(\mathrm{dm}^{3} \cdot \mathrm{ha}^{-1}\right)$} \\
\cline { 2 - 4 } & before sowing & $\begin{array}{c}\text { at growth stage } \\
\text { BBCH 15 }\end{array}$ & total \\
\hline 1. Control & 0 & 0 & 0 \\
\hline 2. $\mathrm{E}_{1}$ & 90 & 0 & 90 \\
\hline 3. $\mathrm{E}_{1}+\mathrm{E}$ & 90 & 40 & 130 \\
\hline 4. $\mathrm{E}_{2}$ & 130 & 0 & 130 \\
\hline 5. $\mathrm{E}_{2}+\mathrm{E}$ & 130 & 40 & 170 \\
\hline 6. $\mathrm{E}_{3}$ & 170 & 0 & 170 \\
\hline 7. $\mathrm{E}_{3}+\mathrm{E}$ & 170 & 40 & 210 \\
\hline 8. $\mathrm{E}_{4}$ & 210 & 0 & 210 \\
\hline 9. $\mathrm{E}_{4}+\mathrm{E}$ & 210 & 40 & 250 \\
\hline
\end{tabular}

Explanation: E - vermi-extract; $\mathrm{BBCH}$ - Biologische Bundesanstalt, Bundessortenamt und Chemische Industrie scale accordind to Zadoks et al. [1974].

and its water content was determined at the same time. At the end of the experiment the contents of $\mathrm{N}, \mathrm{P}, \mathrm{K}, \mathrm{Ca}, \mathrm{Mg}$ and starch in the maize grain, as well as thousand kernel weight (TKW) were determined. Nitrogen was determined by distillation by Kjeldahl method after mineralization in the medium of concentrated $\mathrm{H}_{2} \mathrm{SO}_{4}$ [Cohen 1910]. Phosphorus was determined spectrophotometrically, potassium and calcium by flame photometry, magnesium by atomic absorption spectrophotometry after mineralization in the medium of mixture $\mathrm{HNO}_{3}$ and $\mathrm{HClO}_{4}(2: 1, \mathrm{v} / \mathrm{v})$ [Koppová et al. 1955]. Starch was determined polarimetrically by Ewers method [ISO 10520].

The pot experiment - $22 \mathrm{~kg}$ of Haplic Fluvisol was taken from $0.3 \mathrm{~m}$ of humic horizon into the plastic pots of the diameter $0.35 \mathrm{~m}$ and height of $0.35 \mathrm{~m}$. The agrochemical soil parameters are given in Table 1. The same methods were used to determine agrochemical soil parametres as in the field experiment. The experiment consisted of 3 variants with 5-times repetitions (Table 4).

The vermi-compost was applied in autumn in a dose of $170 \mathrm{~kg} \mathrm{~N} \cdot \mathrm{ha}^{-1}$ into soil of all the variants. The variant 1 was control without treatment of vermi-extract. In variants 2 and 3 the foliar application of vermi-extract was used. This extract was applied once in the dose of 40 $\mathrm{dm}^{3} \cdot \mathrm{ha}^{-1}$ in the variant 2 and twice in doses 40 $\mathrm{dm}^{3} \cdot \mathrm{ha}^{-1}$ of vermi-extract in the variant 3 , totally $80 \mathrm{dm}^{3} \cdot \mathrm{ha}^{-1}$. The first application of extracts was carried out in the growth stage BBCH 12 (var. 2 and 3 ) and the second application in the growth stage BBCH 16 (var. 3). Before the application the extract was diluted by water in the ratio 1 : $25(\mathrm{v} / \mathrm{v})$ and the created vermi-dilution was applied on the maize leaves.

The maize sowing of the hybrid PR38V91 from the company Pioneer (FAO 310) was carried out in the second decade of April. 10 seeds were sown into a pot. The sowing depth was $0.03 \mathrm{~m}$. During the whole growing season the experiment was checked regularly, the state of vegetation health was monitored and before the first application of extracts the number of plants was consolidated to three plants per pot, which left until the end of the maize vegetation.

In the growth stage $\mathrm{BBCH} 17$ the content of nitrogen, phosphorus, potassium, calcium, magnesium, sulphur, zinc, copper, manganese and iron was detected in the aboveground phytomass of maize plants. The same methods were used for the determination of $\mathrm{N}, \mathrm{P}, \mathrm{K}, \mathrm{Ca}$ and $\mathrm{Mg}$ as in the filed trial. Sulphur was determined nephelometrically after mineralization in the medium of mixture $\mathrm{HNO}_{3}$ and $\mathrm{HClO}_{4}(3: 2, \mathrm{v} / \mathrm{v})$ [Koppová et al. 1955]. $\mathrm{Zn}, \mathrm{Cu}, \mathrm{Mn}$ and $\mathrm{Fe}$ were determined by the method of optical emission spectrometry with the inductively coupled plasma after mineralization in mixture of $\mathrm{H}_{2} \mathrm{O}_{2}$ and $\mathrm{HNO}_{3}(1: 5, \mathrm{v} / \mathrm{v})$ in the closed microwave system [Zbíral et al. 2005].

The experiment was terminated in the growth stage $\mathrm{BBCH}$ 97. The grain yield, the weight of aboveground phytomass and thousand kernel weight were detected.

The obtained results were statistically elaborated, analysis of variance (ANOVA) was performed and the differences between the variants were evaluated subsequently by LSD test in the PC program Stathgraphic, version 5.

Table 4. Variants of pot experiment - the term and dose of vermi-extracts and vermi-solution application

\begin{tabular}{|l|c|c|c|c|c|}
\hline \multirow{2}{*}{ Variant } & \multirow{2}{*}{$\begin{array}{c}\text { Term of application } \\
\text { (growth phase) }\end{array}$} & \multicolumn{2}{|c|}{ Dose of vermi-extract } & Dose of vermi-solution \\
\cline { 3 - 6 } & - & $\mathrm{dm}^{3} \cdot \mathrm{ha}^{-1}$ & $\mathrm{~cm}^{3} \cdot \mathrm{plant}^{-1}$ & $\mathrm{~cm}^{3} \cdot \mathrm{pot}^{-1}$ & $\mathrm{~cm}^{3} \cdot \mathrm{pot}^{-1}$ \\
\hline 1. Control & - & - & - & - & \\
\hline 2. E & BBCH 12 & 40 & 0.5 & 1.5 & 39 \\
\hline 3. 2E & BBCH 12 and BBCH 16 & $40+40$ & 0.5 & $1.5+1.5$ & $39+39$ \\
\hline
\end{tabular}

Explanation: see Table 3. 


\section{RESULTS AND DISCUSSION}

\section{Field experiment}

The presowing application of the vermi-compost extract had the evidential impact on the grain yield, the starch content in grain, thousand kernel weight, and phosphorus content in grain of maize (Table 5).

The lowest application dose of extract into soil (var. $\mathrm{E}_{1}$ ) did not increase the grain yield (Table 6). All the other application doses of vermiextract (var. $\mathrm{E}_{2}, \mathrm{E}_{3}, \mathrm{E}_{4}$ ) increased the grain yield of maize in comparison with the control variant. The growths were significant after application the doses of 130 and $170 \mathrm{dm}^{3} \cdot \mathrm{ha}^{-1}$ and insignificant with the dose of $210 \mathrm{dm}^{3} \cdot \mathrm{ha}^{-1}$. The highest yield, and the highest yield increase in relation to the control treatment, was detected in variant $\mathrm{E}_{2}$, wherein $130 \mathrm{dm}^{3} \cdot \mathrm{ha}^{-1}$ of extract was applied before the maize sowing.

The inceased dose of extract in relation to variant $\mathrm{E}_{2}$ had a depressive impact, in spite of that, the yields in the variants $\mathrm{E}_{3}$ and $\mathrm{E}_{4}$ were higher than in the control, unfertilized variant. The obtained data point out the fact that if the presowing application of vermi-extract should result in a considerable increase of yield, it is necessary to apply the doses higher than $90 \mathrm{dm}^{3} \cdot \mathrm{ha}^{-1}$, or it is appropriate to use the doses in the range 130-170 $\mathrm{dm}^{3} \cdot \mathrm{ha}^{-1}$. The obtained results mean the original information in the Slovak environment as so far only the foliar effectiveness of vermi-extract has been tested.

The presowing application of the vermi-compost extract increased considerably also the starch and phosphorus contents in the maize grain. The differences of the starch and phosphorus contents between the variants treated by vermi-extract were minimal, however, we can claim that along with the increase of the application dose of vermiextract the starch and $\mathrm{P}$ content in the maize grain was decreased slightly (Table 5). The vermi-extract usage decreased the TKW, and when 90-170 $\mathrm{dm}^{3} \cdot \mathrm{ha}^{-1}$ was applied the decrease was significant statistically. The presowing utilization of vermiextract did not significantly affect the nitrogen, magnesium, potassium and calcium contents in the maize grain, and grain from the variants 3-5 treated by vermi-extract had lower nitrogen and calcium contents than form the control variant (Table 5 and 6).

The impact of additional fertilizing by the vermi-compost extract in the growth stage $\mathrm{BBCH}$ 15 (Table 7) is evident in comparison to the unpaired variants $(3,5,7,9)$ with the odd ones $(2,4$, $6,8)$. These comparisons prove a positive impact of additional application of vermi-compost extract on the maize grain yield, which increase by 0.63 even $9.14 \%$. This detection corresponds with

Table 5. The impact of resources of variability on maize yield parameters in field experiment

\begin{tabular}{|c|c|c|c|c|c|c|c|c|c|}
\hline \multirow{2}{*}{$\begin{array}{l}\text { Resources of } \\
\text { variability }\end{array}$} & \multirow{2}{*}{$\mathrm{n}$} & Yield & Starch & TKW & $\mathrm{N}$ & $\mathrm{P}$ & K & $\mathrm{Ca}$ & $\mathrm{Mg}$ \\
\hline & & \multicolumn{8}{|c|}{ F - calculated } \\
\hline Variant & 4 & $2.643^{+}$ & $4.741^{+}$ & $5.104^{++}$ & 1.994 & $8.579^{++}$ & 3.407 & 10.683 & 1.334 \\
\hline Repetition & 3 & 0.587 & 0.787 & 1.213 & 0.805 & 0.225 & 0.797 & 0.392 & 0.881 \\
\hline Rest & 12 & & & & & & & & \\
\hline All & 19 & & & & & & & & \\
\hline
\end{tabular}

Explanation: $\mathrm{n}$ - degrees of freedom, TKW - thousand kernel weight.

Table 6. The impact of presowing application of vermicompost extract on the maize yield parameters - field experiment

\begin{tabular}{|l|c|c|c|c|c|c|c|c|c|}
\hline \multirow{2}{*}{ Variant } & Yield & Starch & TKW & $\mathrm{N}$ & $\mathrm{P}$ & $\mathrm{K}$ & \multicolumn{2}{c|}{$\mathrm{Ca}$} & $\mathrm{Mg}$ \\
\cline { 2 - 11 } & $\mathrm{Mg} \cdot \mathrm{ha}^{-1}$ & $\%$ & $\mathrm{~g}$ & \multicolumn{5}{|c|}{$\mathrm{mg} \cdot \mathrm{kg}^{-1} \mathrm{~d} \cdot \mathrm{m}}$. \\
\hline 1. Control & $6.02 \mathrm{a}$ & $62.80 \mathrm{a}$ & $292.51 \mathrm{~b}$ & $16,678 \mathrm{a}$ & $3,051 \mathrm{a}$ & $3,280 \mathrm{a}$ & $873 \mathrm{~b}$ & $1,950 \mathrm{a}$ \\
\hline 2. $\mathrm{E}_{1}$ & $6.02 \mathrm{a}$ & $64.65 \mathrm{~b}$ & $286.09 \mathrm{a}$ & $16,030 \mathrm{a}$ & $3,541 \mathrm{~b}$ & $3,243 \mathrm{a}$ & $859 \mathrm{ab}$ & $2,133 \mathrm{a}$ \\
\hline 3. $\mathrm{E}_{2}$ & $6.30 \mathrm{~b}$ & $64.59 \mathrm{~b}$ & $286.33 \mathrm{a}$ & $15,654 \mathrm{a}$ & $3,529 \mathrm{~b}$ & $3,358 \mathrm{ab}$ & $846 \mathrm{a}$ & $1,932 \mathrm{a}$ \\
\hline 4. $\mathrm{E}_{3}$ & $6.28 \mathrm{~b}$ & $64.11 \mathrm{~b}$ & $286.90 \mathrm{a}$ & $15,958 \mathrm{a}$ & $3,427 \mathrm{~b}$ & $3,237 \mathrm{a}$ & $859 \mathrm{ab}$ & $1,973 \mathrm{a}$ \\
\hline 5. $\mathrm{E}_{4}$ & $6.24 \mathrm{ab}$ & $64.02 \mathrm{~b}$ & $292.04 \mathrm{~b}$ & $16,041 \mathrm{a}$ & $3,411 \mathrm{~b}$ & $3,400 \mathrm{~b}$ & $859 \mathrm{ab}$ & $1,964 \mathrm{a}$ \\
\hline LSD $_{0.05}$ & 0.242 & 0.973 & 4.664 & $1,047.51$ & 199.46 & 154.07 & 5.48 & 204.73 \\
\hline
\end{tabular}

Explanation: E - vermi-extract, LSD $_{0.05}$ - least significant difference at the level $\alpha=0.05$ (LSD test), different letters at values indicate statistically significant differences between treatments. 
Table 7. The impact of sidedress by vermicompost extract on the maize yield parametres - field experiment

\begin{tabular}{|l|c|c|c|c|c|c|c|c|c|}
\hline \multirow{2}{*}{ Variant } & \multicolumn{4}{|c|}{ Yield } & \multicolumn{3}{c|}{ Starch } & \multicolumn{3}{c|}{ TKW } \\
\cline { 2 - 10 } & $\mathrm{Mg} \cdot \mathrm{ha}^{-1}$ & $\%^{*}$ & $\%^{* *}$ & $\mathrm{~g} \cdot \mathrm{kg}^{-1}$ & $\%^{*}$ & $\%^{* *}$ & $\mathrm{~g}$ & $\%^{*}$ & $\%^{* *}$ \\
\hline 1. Control & 6.02 & 100.00 & - & 628.0 & 100.00 & - & 292.51 & 100.00 & - \\
\hline 2. $\mathrm{E}_{1}$ & 6.02 & 100.00 & 100.00 & 646.5 & 102.95 & 100.00 & 286.09 & 97.81 & 100.00 \\
\hline 3. $\mathrm{E}_{1}+\mathrm{E}$ & 6.57 & 109.14 & 109.14 & 643.4 & 102.45 & 99.52 & 283.55 & 96.94 & 99.11 \\
\hline 4. $\mathrm{E}_{2}$ & 6.30 & 104.65 & 100.00 & 645.9 & 102.85 & 100.00 & 286.33 & 97.89 & 100.00 \\
\hline 5. $\mathrm{E}_{2}+\mathrm{E}$ & 6.34 & 105.31 & 100.63 & 638.4 & 101.66 & 98.84 & 290.00 & 99.14 & 101,28 \\
\hline 6. $\mathrm{E}_{3}$ & 6.28 & 104.32 & 100.00 & 641.1 & 102.09 & 100.00 & 286.90 & 98.08 & 100.00 \\
\hline 7. $\mathrm{E}_{3}+\mathrm{E}$ & 6.37 & 105.81 & 101.43 & 645.6 & 102.80 & 100.70 & 283.87 & 97.05 & 98.94 \\
\hline 8. $\mathrm{E}_{4}$ & 6.24 & 103.65 & 100.00 & 640.2 & 101.94 & 100.00 & 292.04 & 99.84 & 100.00 \\
\hline 9. $\mathrm{E}_{4}+\mathrm{E}$ & 6.79 & 112.79 & 108.81 & 646.4 & 102.93 & 100.97 & 286.54 & 97.96 & 98.12 \\
\hline
\end{tabular}

Explanation: E - vermi-extract, $*$ Control $=100 \%$, ** presowing application $=100 \%$.

the finding of Klimeková et al. [2007] recorded the yield increase only by $1.83 \%$ after application of $50 \mathrm{dm}^{3} \cdot \mathrm{ha}^{-1}$ vermi-extract on the winter wheat leaves in the growth stage BBCH 32. The above mentioned information cooresponds also with the finding of Singh et al. [2010] who stated 9.8 to $13.9 \%$ increase of strawberry yield after the vermi-extract application. In neither case the decrease of grain yield was recorded after the foliar extract application (Table 7).

The highest increase of grain yield as the result of the foliar application of vermi-extract $(9.14 \%)$ was recorded in the variant 3 versus variant 2, where the lowest quantity of extract was applied in the presowing period.

The increase of the maize grain yield after the foliar application of extract varied in the broader range than after the application of vermi-extract into soil ( 0.63 to $9.14 \%$ versus 0.0 to $4.65 \%$ ). The average increase of the grain yield after the foliar application achieved the level of 5.00\% and after the application into soil only $3.16 \%$. It is evident that a lower dose of extract $\left(40 \mathrm{dm}^{3} \cdot \mathrm{ha}^{-1}\right)$ applied on a leaf can have a higher impact on the yield formation of maize grain in comparison with higher doses of extract ( 90 to $210 \mathrm{dm}^{3} \cdot \mathrm{ha}^{-1}$ ) applied into soil.

The common effect of the presowing and foliar application of vermi-extract compared with the control, untreated by vermi-extract variant, increased the grain yield by 5.31 to $12.79 \%$ (variants 3, 5, 7, 9 versus control).

Additional fertilization by the extract in the growth stage $\mathrm{BBCH} 15$ (odd variants versus even variants) had smaller effect on starch content and thousand kernel weight, than on the grain yield, or the given parameters were not influenced by the foliar application of vermi-extract at all. There were differences only at the level of 0.48 to $1.78 \%$.

The impact of the foliar application of vermiextract on the nitrogen, and also phosphorus and magnesium content was negative (Table 8).

The nitrogen content fell by 1.09 to $5.52 \%$, phosphorus content by 0.28 to $5.10 \%$ and magnesium content by 6.1 to $9.69 \%$. The recorded de-

Table 8. The impact of sidedress by vermicompost extract on the contents of some macroelements in maize grain - field experiment

\begin{tabular}{|l|c|c|c|c|c|c|c|c|c|c|}
\hline \multirow{2}{*}{ Variant } & \multicolumn{2}{|c|}{$\mathrm{N}$} & \multicolumn{2}{c|}{$\mathrm{P}$} & \multicolumn{2}{c|}{$\mathrm{K}$} & \multicolumn{2}{c|}{$\mathrm{Ca}$} & \multicolumn{2}{c|}{$\mathrm{Mg}$} \\
\cline { 2 - 14 } & $\mathrm{g} \cdot \mathrm{kg}^{-1}$ & $\%^{*}$ & $\mathrm{~g} \cdot \mathrm{kg}^{-1}$ & $\%^{*}$ & $\mathrm{~g} \cdot \mathrm{kg}^{-1}$ & $\%^{*}$ & $\mathrm{~g} \cdot \mathrm{kg}^{-1}$ & $\%^{*}$ & $\mathrm{~g} \cdot \mathrm{kg}^{-1}$ & $\%^{*}$ \\
\hline 2. $\mathrm{E}_{1}$ & 16.00 & 100.00 & 3.54 & 100.00 & 3.24 & 100.00 & 0.86 & 100.00 & 2.13 & 100.00 \\
\hline 3. $\mathrm{E}_{1}+\mathrm{E}$ & 15.20 & 95.00 & 3.53 & 99.72 & 3.33 & 102.78 & 0.87 & 101.16 & 2.00 & 93.90 \\
\hline 4. $\mathrm{E}_{2}$ & 15.65 & 100.00 & 3.53 & 100.00 & 3.36 & 100.00 & 0.85 & 100.00 & 1.93 & 100.00 \\
\hline 5. $\mathrm{E}_{2}+\mathrm{E}$ & 15.48 & 98.91 & 3.35 & 94.90 & 3.48 & 103.57 & 0.85 & 100.00 & 1.81 & 93.78 \\
\hline 6. $\mathrm{E}_{3}$ & 15.96 & 100.00 & 3.43 & 100.00 & 3.24 & 100.00 & 0.86 & 100.00 & 1.97 & 100.00 \\
\hline 7. $\mathrm{E}_{3}+\mathrm{E}$ & 15.08 & 94.48 & 3.39 & 98.83 & 3.44 & 106.17 & 0.86 & 100.00 & 1.81 & 91.88 \\
\hline 8. $\mathrm{E}_{4}$ & 16.04 & 100.00 & 3.41 & 100.00 & 3.40 & 100.00 & 0.86 & 100.00 & 1.96 & 100.00 \\
\hline 9. $\mathrm{E}_{4}+\mathrm{E}$ & 15.44 & 96.26 & 3.36 & 98.53 & 3.49 & 102.65 & 0.87 & 101.16 & 1.77 & 90.31 \\
\hline
\end{tabular}

Explanation: E - vermi-extract, * presowing application $=100 \%$. 
crease of the nitrogen content in the maize grain along with the parallel increase of maize grain yield corresponds with the data of Kováčik [2014] who claims that the decrease of the nitrogen content in the grains of cereals often occurs after the application of the growth stimulators without the simultaneous application of the nitrogen fertilizers. The rate of the $\mathrm{N}$ content drop in grains is determined by several factors, among which the unfavourable weather and the insufficient $\mathrm{N}_{\text {an }}$ content in soil rank among the most important factors.

\section{Pot experiment}

The obtained results (Table 9) show that it is evident the maize plants in the control variant 1 were higher before the extract application than the plants in the variants treated by vermiextract. However, after 13-20 days from the first application by vermi-extract ( $6^{\text {th }}$ and $13^{\text {th }}$ of June) the plants treated by extract (var. 2 and 3 ) were higher than those in the control variant. In the following week ( $21^{\text {st }}$ of June) these differences in height were eliminated. The increase in plant height treated by extract was recorded nine days after the second spraying (28 $8^{\text {th }}$ June) similarly like after the first spraying (var. 3 versus var. 2 ). The plants of the variant 3 were the highest ones, and of the control variant were the lowest ones. In the middle of July, in the growth stage BBCH 18 and also in the following stages (BBCH 51, 59-61) the highest plants were recorded in the control variant. This means that the positive impact of the foliar application of extract on the maize plant height is evident during the first 20 days after spraying and with the older plants during the first 10 days. However, the plant height recorded at the end of the growing season refers that the stimulative effect is only the short-term one and the extract had the inhibitive impact on the plant height afterward. The detected information about the short-term stimulative effect of vermi-extracts on the plant phytomass is significant. It explains the reason of positive effects of vermi-extracts on the plant phytomass publishing in many scientific articles because they present the results of experiments lasted for only 5 or 6 weeks.

The impact of the extract application on the maize stalk thickness was the same till the growth stage BBCH 14 as the impact on the height of maize plants (Table 10). 13 days after the first application of vermi-extract $\left(6^{\text {th }}\right.$ June) the plants treated by extract (var. 2 and 3 ) were considerably thicker than the plants in the control variant.

Table 9. The impact of one and two applications of vermi-extract on dynamics of maize growth - pot experiment

\begin{tabular}{|c|c|c|c|c|c|c|c|c|c|}
\hline \multirow{5}{*}{ Variant } & \multicolumn{9}{|c|}{ Date } \\
\hline & 21.V. & 29.V. & 6.VI. & 13.VI. & 21.VI. & 28.VI. & 15.VII. & 25.VII. & 5.VIII. \\
\hline & \multicolumn{9}{|c|}{$\mathrm{BBCH}$} \\
\hline & 12 & 13 & 14 & $14-15$ & $16-17$ & $17-18$ & 18 & 51 & $59-61$ \\
\hline & \multicolumn{9}{|c|}{$\mathrm{cm}$} \\
\hline 1. Control & $8.33 \mathrm{~b}$ & $12.88 \mathrm{~b}$ & $14.44 \mathrm{a}$ & $19.88 \mathrm{a}$ & $36.00 \mathrm{a}$ & $45.16 \mathrm{a}$ & $60.22 \mathrm{~b}$ & $105.44 \mathrm{~b}$ & $128.11 \mathrm{~b}$ \\
\hline 2. $E$ & $7.55 \mathrm{a}$ & $11.33 \mathrm{a}$ & $15.05 \mathrm{~b}$ & $22.94 \mathrm{~b}$ & $36.01 \mathrm{a}$ & $48.88 \mathrm{~b}$ & $55.77 \mathrm{a}$ & 99.11 a & $118.11 \mathrm{a}$ \\
\hline 3. $2 \mathrm{E}$ & $7.55 \mathrm{a}$ & $11.33 \mathrm{a}$ & $15.05 \mathrm{~b}$ & $24.00 \mathrm{~b}$ & $36.01 \mathrm{a}$ & $52.05 \mathrm{c}$ & $58.44 \mathrm{~b}$ & $104.00 \mathrm{~b}$ & $118.00 \mathrm{a}$ \\
\hline LSD $_{0.05}$ & 0.648 & 1.203 & 0.576 & 2.308 & 0.287 & 2.942 & 1.836 & 2.849 & 3.718 \\
\hline
\end{tabular}

Explanation: The first extract application was carried out on $24^{\text {th }}$ of May (BBCH 12) and the second application on $19^{\text {th }}$ of June $(\mathrm{BBCH} 16)$. E - vermi-extract, $\mathrm{LSD}_{0.05}$ - least significant difference at the level $\alpha=0.05$ (LSD test), different letters at values indicate statistically significant differences between treatments.

Table 10. The impact of one and two applications of vermi-extract on dynamics of maize stalk coarsening - pot experiment

\begin{tabular}{|c|c|c|c|c|c|c|c|c|c|}
\hline \multirow{5}{*}{ Variant } & \multicolumn{9}{|c|}{ Date } \\
\hline & 21.V. & 29.V. & 6.VI. & 13.VI. & 21.VI. & 28.VI. & 15.VII. & 25.VII. & 5.VIII. \\
\hline & \multicolumn{9}{|c|}{$\mathrm{BBCH}$} \\
\hline & 12 & 13 & 14 & $14-15$ & $16-17$ & $17-18$ & 18 & 51 & 59-61 \\
\hline & \multicolumn{9}{|c|}{$\mathrm{cm}$} \\
\hline 1. Control & $2.03 \mathrm{a}$ & $2.24 \mathrm{a}$ & $2.47 \mathrm{a}$ & $3.15 a$ & $4.16 \mathrm{a}$ & $5.02 b$ & $4.58 \mathrm{ab}$ & $4.52 \mathrm{a}$ & $4.46 \mathrm{~b}$ \\
\hline 2. $\mathrm{E}$ & $2.04 \mathrm{a}$ & $2.26 \mathrm{a}$ & $2.66 \mathrm{~b}$ & $3.17 \mathrm{a}$ & $4.34 \mathrm{~b}$ & $5.17 \mathrm{~b}$ & $4.74 \mathrm{~b}$ & $4.65 a$ & $4.28 a b$ \\
\hline 3. $2 \mathrm{E}$ & $2.04 \mathrm{a}$ & $2.26 \mathrm{a}$ & $2.70 \mathrm{~b}$ & $3.17 \mathrm{a}$ & $4.02 \mathrm{a}$ & $4.21 \mathrm{a}$ & $4.36 \mathrm{a}$ & $4.48 a$ & $4.21 \mathrm{a}$ \\
\hline LSD $_{0.05}$ & 0.114 & 0.129 & 0.142 & 0.108 & 0.159 & 0.563 & 0.372 & 0.307 & 0.208 \\
\hline
\end{tabular}

Explanation: see Table 9 . 
The second application of the extract carried out in stage BBCH 16 (var. 3), i.e. 9 days after spraying $\left(28^{\text {th }}\right.$ June) had evidently an inhibitive impact.

The stalks were getting thicker, however, they grew considerably slower and for longer time than the stalks of the other two variants. These data correspond partially with the information by Gutiérrez-Miceli et al. [2008], who recorded thinner stalks of the sorghum plants (Sorghum bicolor) in some cases after the vermi-extract application in comparison with the control variant.

In the variants 1 and 2 the stalk girth was decreased from the end of the growth stage $\mathrm{BBCH}$ 18 . In the variant 3 , wherein the second dose of extract was also applied, the stalks were getting thinner after the growth stage BBCH 51. These data point out indirectly that the extract application carried out in stage BBCH 16 delayed the maturation of stalk tissues and the transfer of the assimilates from the vegetative parts of plant to grain (Table 10).

In the growth stage BBCH 59-61 the thickest stalks were recorded in the control variant - untreated by extract, and the narrowest stalks occurred in the variant where the extract was applied twice (var. 3). Similarly, the highest yield of maize grain and straw was detected in the control variant, and the lowest yield was obtained in variant 3 .

These facts result in the information that plant height and thickness of maize stalks recorded in the growth stages BBCH 12 to BBCH 51 did not correspond with the achieved quantity of maize grain yield. On the contrary, it is possible to detect a certain relationship between the plant height, stalk thickness and grain yield only in the growth stage BBCH 59-61. These data prove the information of Kováčik [2014] that it is not unusual if the vegetation of field crops looks better optically (higher, more dark green) until the first half of the growing season but it gives lower yields than the vegetation which appears to be weaker.

The lower grain yields in the variants treated by extract, recorded in the pot experiment (Table 11 ), are in contrast with the data of field experiment presented in the Table 7.

The data show that in neither case the decrease of grain yield was recorded after the foliar application of extract. The reason for different effects of the identical vermi-extract on the yield of maize grain consists probably in the different dates of extract application and in the different maize cultivars. In the field experiment the extract was applied in the growth stage BBCH 15 and the cultivar Stira was grown. Whereas, in the pot experiment the extract was applied in growth stages $\mathrm{BBCH} 12$ or in $\mathrm{BBCH} 12$ and 16, and the cultivar hybrid PR38V91 was grown.

The negative effect of the foliar application of extract on the vegetative phytomass was more considerable (9.14 to $18.5 \%$ ) in comparison with the impact on the generative phytomass $(0.24$ to $11.3 \%)$. This caused a change of ratio between

Table 11. The impact of single and double application of vermi-extract on maize yield parametres - pot experiment

\begin{tabular}{|c|c|c|c|c|c|c|c|}
\hline \multirow{3}{*}{ Variant } & \multicolumn{4}{|c|}{ Yield } & \multirow{3}{*}{$\begin{array}{c}\text { Grain/straw } \\
\text { ratio }\end{array}$} & \multirow{2}{*}{\multicolumn{2}{|c|}{ TKW }} \\
\hline & \multicolumn{2}{|c|}{ grain } & \multicolumn{2}{|c|}{ straw } & & & \\
\hline & $g \cdot$ pot $^{-1}$ & $\%^{*}$ & $\mathrm{~g} \cdot \mathrm{pot}^{-1}$ & $\%^{*}$ & & g & $\% *$ \\
\hline 1. Control & $54.24 \mathrm{~b}$ & 100.00 & $101.95 \mathrm{bc}$ & 100.00 & 0.510 & $251.44 \mathrm{a}$ & 100.00 \\
\hline 2. $\mathrm{E}$ & $54.11 \mathrm{~b}$ & 99.76 & $92.63 a b$ & 90.86 & 0.584 & $253.53 \mathrm{a}$ & 100.83 \\
\hline 3. $2 \mathrm{E}$ & $48.11 \mathrm{a}$ & 88.70 & $83.09 \mathrm{a}$ & 81.50 & 0.579 & $255.04 \mathrm{~b}$ & 101.43 \\
\hline LSD $_{0.05}$ & 3.543 & & 10.274 & & & 3.243 & \\
\hline
\end{tabular}

Explanation: see Table 9, * Control $=100 \%$.

Table 12. The impact of single and double application of vermi-extract on some macroelements $(\mathrm{N}, \mathrm{P}, \mathrm{K})$ contents in plants of maize in the growth stage BBCH17 - pot experiment

\begin{tabular}{|l|c|c|c|c|c|c|}
\hline \multirow{2}{*}{ Variant } & \multicolumn{2}{|c|}{$\mathrm{N}$} & \multicolumn{2}{c|}{$\mathrm{P}$} & \multicolumn{2}{c|}{$\mathrm{K}$} \\
\cline { 2 - 7 } & $\mathrm{mg} \cdot \mathrm{kg}^{-1}$ & $\%^{*}$ & $\mathrm{mg} \cdot \mathrm{kg}^{-1}$ & $\%^{*}$ & $\mathrm{mg} \cdot \mathrm{kg}^{-1}$ & 10.00 \\
\hline 1. Control & $12,894 \mathrm{a}$ & 100.00 & $4,048 \mathrm{~b}$ & 100.00 & $33,466 \mathrm{a}$ & 99.20 \\
\hline 2. E & $13,263 \mathrm{~b}$ & 104.41 & $4,386 \mathrm{c}$ & 108.35 & $33,197 \mathrm{a}$ & 94.36 \\
\hline 3. 2E & $13,084 \mathrm{~b}$ & 101.47 & $3,779 \mathrm{a}$ & 93.35 & $31,577 \mathrm{a}$ & $1,935.324$ \\
\hline LSD $_{0.05}$ & 220.124 & & 185.458 & & & \\
\hline
\end{tabular}

Explanation: E - vermi-extract, $\mathrm{LSD}_{0.05}$ - least significant difference at the level $\alpha=0.05$ (LSD test), different letters at values indicate statistically significant differences between treatments, ${ }^{*}$ Control $=100 \%$. 
Table 13. The impact of single and double application of vermi-extract on some macroelements $(\mathrm{Ca}, \mathrm{Mg}, \mathrm{S})$ contents in plants of maize in the growth stage $\mathrm{BBCH} 17$ (pot experiment)

\begin{tabular}{|l|c|c|c|c|c|c|}
\hline \multirow{2}{*}{ Variant } & \multicolumn{2}{|c|}{$\mathrm{Ca}$} & \multicolumn{2}{c|}{$\mathrm{Mg}$} & \multicolumn{2}{c|}{$\mathrm{S}$} \\
\cline { 2 - 7 } & $\mathrm{mg} \cdot \mathrm{kg}^{-1}$ & $\%^{*}$ & $\mathrm{mg} \cdot \mathrm{kg}^{-1}$ & $\%^{*}$ & $\mathrm{mg} \cdot \mathrm{kg}^{-1}$ & $\%^{*}$ \\
\hline 1. Control & $1876 \mathrm{~b}$ & 100,00 & $5174 \mathrm{c}$ & 100,00 & $337 \mathrm{a}$ & 100,00 \\
\hline 2. E & $1714 \mathrm{a}$ & 91,36 & $3727 \mathrm{~b}$ & 72,03 & $270 \mathrm{a}$ & 80,12 \\
\hline 3. 2E & $1660 \mathrm{a}$ & 88,49 & $3001 \mathrm{a}$ & 58,00 & $304 \mathrm{a}$ & 90,21 \\
\hline LSD $_{0.05}$ & 136,214 & & 313,628 & & 88,957 & \\
\hline
\end{tabular}

Explanation: see Table 12.

Table 14. The impact of single and double application of vermi-extract on some microelements $(\mathrm{Zn}, \mathrm{Cu}, \mathrm{Mn}, \mathrm{Fe})$ contents in plants of maize in the growth stage $\mathrm{BBCH} 17$ (pot experiment)

\begin{tabular}{|l|c|c|c|c|c|c|c|c|}
\hline \multirow{2}{*}{ Variant } & \multicolumn{2}{|c|}{ Zn } & \multicolumn{2}{c|}{$\mathrm{Cu}$} & \multicolumn{2}{c|}{$\mathrm{Mn}$} & \multicolumn{2}{c|}{$\mathrm{Fe}$} \\
\cline { 2 - 10 } & $\mathrm{mg} \cdot \mathrm{kg}^{-1}$ & $\%^{*}$ & $\mathrm{mg} \cdot \mathrm{kg}^{-1}$ & $\%^{*}$ & $\mathrm{mg} \cdot \mathrm{kg}^{-1}$ & $\%^{*}$ & $\mathrm{mg}^{-1} \mathrm{~kg}^{-1}$ & $\%^{*}$ \\
\hline 1. Control & $55.85 \mathrm{~b}$ & 100,00 & $3.92 \mathrm{ab}$ & 100.00 & $49.62 \mathrm{~b}$ & 100.00 & $339.34 \mathrm{c}$ & 100.00 \\
\hline 2. E & $53.16 \mathrm{~b}$ & 95,18 & $4.26 \mathrm{~b}$ & 111.52 & $51.05 \mathrm{c}$ & 102.88 & $294.38 \mathrm{~b}$ & 86.75 \\
\hline 3. 2E & $52.02 \mathrm{~b}$ & 93,14 & $3.80 \mathrm{ab}$ & 99.48 & $47.38 \mathrm{a}$ & 95.49 & $272.87 \mathrm{ab}$ & 80.41 \\
\hline LSD $_{0.05}$ & 4.074 & & 0.586 & & 1.408 & & 29.047 & \\
\hline
\end{tabular}

Explanation: see Table 12.

grain and straw in favour of grain. The extract utilization had the positive impact on the TKW.

The remarkable fact is that the contents of phosphorus, potassium, calcium, magnesium, zinc, copper, manganese and iron were lower in the growth stage $\mathrm{BBCH} 17$, one week after the second application of extract, in comparison with the other variants (Tables 12, 13 and 14).

These data indicate a wide-spectral inhibition of nutrients intake as a result of foliar application of vermi-extract. Similarly, Gutiérrez-Miceli et al. [2008] recorded the decrease of N, P and K contents in the sorghum plants in the majority of cases after the application of extracts. On the contrary, Pant et al. [2012] detected a increase of N, $\mathrm{P}, \mathrm{K}, \mathrm{Ca}$ and $\mathrm{Mg}$ content in the plants of pak choi after using several types of vermi-extracts.

\section{CONCLUSION}

1. The vermi-extract applied in the presowing period increased the maize grain yield if the application doses were at the level of 130 to 170 $\mathrm{dm}^{3} \cdot \mathrm{ha}^{-1}$. In order to increase the starch content in grain it is more suitable to carry out the presowing application of vermi-extract than the application during the growing season.

2. The positive or negative impact of the foliar vermi-extract application on the maize grain yield depended on the date of the extract ap- plication and the grown cultivar. The presowing application and foliar application of vermi-extract tended to decrease the nitrogen content in grain.

3. The foliar application of vermi-extract positively affected plant height and stalk thickness of maize only in the short term. The plant height and stalk thickness of maize recorded in the growth stages $\mathrm{BBCH} 12$ to $\mathrm{BBCH} 51$ did not correspond with the achieved quantity of maize grain yield. In the first half of the maize growing season the information about the plant height and stalk thickness was not an appropriate indicator for the prognostication of quantity of maize grain yield.

\section{Acknowledgements}

This research was supported by the projects VEGA 1/0591/13 and VEGA 2/0079/13.

\section{REFERENCES}

1. Arancon N.Q., Edwards C.A., Bierman P., Welch C., Metzger, J.D. 2004. Influences of vermicomposts on field strawberries: 1. Effects on growth and yields. Bioresour. Technol., 93 (2), 145-153. doi:10.1016/j.biortech.2003.10.014.

2. Arancon N.Q., Edwards C.A., Bierman P., Metzger J.D., Lucht C. 2005. Effect of vermicomposts produced from cattle manure, food waste and paper 
waste on the growth and yield of peppers in the field. Pedobiologia, 49 (4), 297-306. doi:10.1016/j. pedobi.2005.02.001.

3. Bremner J.M. 1960. Determination of nitrogen in soil by the Kjeldahl method. J. Agric. Sci., 55 (1), 11-33. doi:10.1017/S0021859600021572.

4. Chalker-Scott L. 2005. The myth of compost tea, Episode III: Aerobically-brewed compost tea suppresses disease. [online:] www.puyallup.wsu.edu/ Linda\%20Chalker-Scott/Horticultural\%20Myths_ files/Myths/Compost $\% 20$ tea\%203rd\%20time.pdf.

5. Cohen J.B. 1910. Practical Organic Chemistry. MacMillan and Co., Limited; St. London, pp. 356.

6. Fiala K., Kobza J., Matúšková L', Brečková V., Makovníková J., Barančíková G., Búrik V., Litavec T., Houšková B., Chromaničová A., Váradiová D., Pechová B. 1999. Záväzné metódy rozborov pôd. Bratislava: VÚPOP, pp. 142.

7. Frederickson J. 2002. Vermicomposting trials at the worm research centre: part 1. Technical evaluation. Integrated Waste Systems, Open University, pp. 107.

8. García-Gómez R.C., Dendooven L., Gutiérrez-Miceli F.A. 2008. Vermicomposting leachate (worm tea) as liquid fertilizer for maize (Zea mays L.) forage production. Asian J. Plant Sci., 7 (4), 360367. doi:10.3923/ajps.2008.360.367.

9. Ghorbani R., Koocheki A., Jahan M., Asadi G.A. 2008. Impact of organic amendments and compost extracts on tomato production and storability in agroecological systems. Agron. Sustain. Dev., 28, 307-311. doi:10.1051/agro:2008003.

10. Gutiérrez-Miceli F.A., García-Gómez R.C., Rincón Rosales R., Abud-Archila M., Llaven O.M.A., Cruz M.J.G., Dendooven L. 2008. Formulation of a liquid fertilizer for sorghum (Sorghum bicolor L. Moench) using vermicompost leachate. Bioresource Technology, 99, 6174-6180. doi:10.1016/j. biortech.2007.12.043.

11. Grappelli A., Galli E., Tomati U. 1987. Earthworm casting effect on Agaricus bisporus fructification. Agrochimica, 21, 457-462.

12. Ingham E.R. 2005. The Compost Tea Brewing Manual: Latest methods and research. Soil Food Web, Corvallis, OR, $5^{\text {th }}$ ed. $79 \mathrm{p}$.

13. ISO 10520. 1997. Native starch - Determination of starch content - Ewers polarimetric method, International Standard (E).

14. Klimeková M., Lehocká Z., Žák Š. 2007. The effect of three forecrops and Vermisol application on yields and baking quality of winter wheat in organic farming system. In: Proceeding of conference Organic farming 2007, CULS in Prague, 53-55.

15. Kmet'ová M., Kováčik P. 2014. The impact of vermicompost application on the yield parameters of maize (Zea mays L.) observed in selected phenological growth stages (BBCH-scale). Acta fytotechn. Zootechnica, 17 (4), 100-108. doi:10.15414/ afz.2014.17.04.100-108.

16. Koppová A., Pirkl J., Kalina J. 1955. Stanovění popelovin $\mathrm{v}$ rostlinném materiálu přesními expeditívními metodami. Vědecké práce VÚRV, Praha, 1955.

17. Kostecka J. 2009. Selected aspects of the significance of earthworms in the context of sustainable waste management. In: Contemporary Problems of Management and Environmental Protection. W. Sądej (Ed.) Sevages and waste materials in environment. Olsztyn, 153-170.

18. Kováčik P. 1997. Rozbory pôd, rastlín, hnojív a výpočet dávok živín k pol’ným a záhradným plodinám. Nitra: SPU v Nitre, 99 pp,

19. Kováčik P. 2014. Princípy a spôsoby výživy rastlín. Nitra, SPU v Nitre, pp. 278.

20. Lanthier M. 2007. Compost tea and its impact on plant diseases. BC Organic Grower. 10 (2), 8-11.

21. Ložek O., Fecenko, J. 1998. Vplyv Vermisolu v kombinácii s dusíkatou výživou na úrodu a kvalitu zrna ozimnej pšenice. Pol'nohospodárstvo, 44 (11), 835-846.

22. Mehlich, A. 1984. Mehlich 3 soil test extractant: A modification of Mehlich 2 extractant. Communication in Soil Science and Plant Analysis, 15, 14091416. doi:10.1080/00103628409367568.

23. Pant A.P., Radovich T.J.K., Hue N.V., Talcott S.T., Krenek K.A. 2009. Vermicompost extracts influence growth, mineral nutrients, phytonutrients and antioxidant activity in pak choi (Brassica rapa cv. Bonsai, Chinensis group) grown under vermicompost and chemical fertilizer. Journal of the Science of Food and Agriculture, 89 (14), 2383-2392. doi:10.1002/jsfa.3732.

24. Pant A.P., Radovich T.J.K., Hue N.V., Paull R.E. 2012. Biochemical properties of compost tea associated with compost quality and effects on pak choi growth. Scientia Horticulturae, 148, 138-146. doi. org/10.1016/j.scienta.2012.09.019.

25. Singh R., Sharma R.R., Kumar S., Gupta R. K., PATIL R. T. 2008. Vermicompost substitution influence growth, physiological disorders, yield and quality of strawberry (Fragaria ananassa Duch.). Bioresour. Technol., 99 (17), 8507-8511. doi:10.1016/j.biortech.2008.03.034.

26. Singh R., Gupta R.K., Patil R.T., Sharma R.R., Asrey R., Kumar A., Jangra K.K. 2010. Sequential foliar application of vermicompost leachates improves marketable fruit yield and quality of strawberry (Fragaria ananassa Duch.). Scientia Horticulturae, 124, 34-39. doi:10.1016/j.scienta.2009.12.002. 
27. Scheuerell S., Mahaffee W. 2002. Compost tea: Principles and prospects for plant disease control. Compost Science and Utilization, 10 (4), 313-338. doi:10.1080/1065657X.2002.10702095.

28. Scheuerell S.J. 2004. Compost tea production practices, microbial properties, and plant disease suppression. I International conference Soil and compost eco-biology, September $15^{\text {th }}-17^{\text {th }} 2004$, León-Spain, 41-51.

29. Tejada M., Gonzalez J.L., Hernandez M.T., Gracia C. 2008. Agricultural use of leachates obtained from two different vermicomposting processes. Bioresour. Technol., 99 (14), 6228-6232. doi:10.1016/j.biortech.2007.12.031.

30. Tomati U., Grappelli A., Galli E. 1988. The hormone-like effect of earthworm casts on plant growth. Biology and Fertility of Soils. 5 (4), 288294. doi:10.1007/BF00262133.

31. Tomati U., Galli E. 1995. Earthworms, soil fertility and plant productivity. Acta Zoologica Fennica, 196, 11-14.

32. Utkhede R., Koch C. 2004. Biological treatments to control bacterial canker of greenhouse tomatoes. Biocontrol, 49 (3), 305-313. doi:10.1023/ B:BICO.0000025373.69584.08.

33. Tiurin I.V. 1966. K metodike analiza deja sravnítel'nogo izučenja sostava počvennogo peregnoja ili gumusa. Voprosy genezisa i plodorodija počv. Moskva: Nauka, 1966.

34. Weltzien H.C. 1991. Biocontrol of foliar fungal disease with compost extracts. [In:] Microbial Ecology of Leaves, Springer-Verlag, New York, p. 430-450. ISBN 978-1-4612-7822-1. doi:10.1007/978-1-4612-3168-4_22.

35. Wickland L., Murray T., Jimerson J. 2001. Brewing up solutions to pest problems. BioCycle, 42, 64-66.

36. Zaller J.G. 2006. Foliar spraying of vermicompost. extracts: Effects on fruit quality and indications of late-blight suppression of field-grown tomatoes. Biological agriculture and horticulture. 24 (2), 165-180. doi:10.1080/01448765.2006.9755017.

37. Zbíral J., Urbánková E., Čižmárová E., Tieffová P., Rychlý M., Šulová R., Kabátová N., Pospíchalová Markéta; Souček Jaromír, Keilová R., Srnková J. 2005. Analýza rostlinného materiálu. Jednotné pracovní postupy ÚKZÚZ. II. přepracované a rozšířené vydání. Národní referenční laboratoř ÚKZÚZ Brno, pp. 192.

38. Zadoks J.C., Chang T.T., Konzak C.F. 1974. A decimal code for the growth stages of cereals. Weed Research, 14 (6): 415-421. doi:10.1111/j.1365-3180.1974.tb01084.x. 